\title{
The Analysis of Pine Needles as a Substrate for Gasification
}

Alok Dhaundiyal and Dr.V.K. Gupta

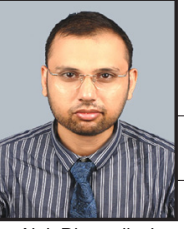

Alok Dhaundiyal

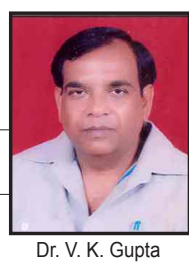

Dr. V. K. Gupta

Abstract: The forests of Chir pine (Pinus Roxburgii) encompass 97.4 thousand acres or $16.15 \%$ of the total forest land of Uttrakhand, a state in India. According to Forest Department of India, Dehradun, a massive forest fire in 1995 engulfed 14.7 thousand acres of valuable forest area through 2,272 forest fire incidents in Uttrakhand, which resulted in the loss of crores of rupees and created various long-lasting ecological consequences. The fires damaged the fertile top layer of the soil and left a layer of pine needle litter that prevented rain water from being absorbed by the soil and contributed to early depletion of the groundwater cycle and stopped grass growth, thus depriving livestock of important food. So the question of what to do with these pine needles is an important one for forest and livestock. Regarding this problem, the German organization, Deutsche Gesellschaft für Internationale Zusammenarbeit, has been studying ways to use pine needles as a feedstock for downdraft gasifiers. If successful, the gasifier would provide incentive to collect the pine needles during dry months and improve the condition of the soil by allowing water to permeate top soils. Using chemical analysis, flue gas analysis, and combustion analysis, our paper analyzes the potential of pine needles as a substrate for gasification. We also argue that using pine needles in this way would alleviate carbon dioxide emissions due to forest fire. Average carbon dioxide emissions in forests that have an abundance of pine needles is $15.46 \%$, but reduced to $12.8 \%$ when pine needles are used in a gasifier plant.

Key words: Chemical analysis, Flue gas analysis, Combustion analysis, India

\section{Introduction}

Tndia is highly dependent on fossil fuels and this result in high green house gas emissions, which causes climate change. In kitchens in urban areas, liquid propane gas (LPG) is most commonly used which is expensive and polluting. Whereas, in rural areas, people rely on firewood as the primary fuel, which causes indoor air pollution and releases harmful black smoke.

However, several million tonnes of pine needles are abundant in both the Garhwal and Kumaon regions of Uttarakhand. These may be used in place of firewood. If pine needles are not removed they can precipitate many problems to the environment. For one, they are highly combustible which can intensify forest fires. Second, pine needles form a layer on the ground and prevent rain water from reaching the soil. Third, pine needles inhibit grass growth, which diminishes food stocks for cattle. So there are many reasons to remove pine needles from forest floors. On the positive side, the combustible nature of pine needles might be harnessed as a fuel through gasification for rural residents.

Pine needle gasification, apart from meeting the rural energy needs, should be able to generate rural employment while protecting the forests from fire. The conversion of pine needles into fuel gases or electricity immediately gives it an economic value, and thus provides motivation for people to collect them. Once pine needles are cleared, fire risk is lowered, biodiversity is protected, and food for livestock is enhanced. This conversion of pine needles into usable fuel, apart from saving the forests from fire, would also save the forest from fuel wood pressure.

Nearly a billion and a half people worldwide have no access to electricity, and approximately 2.7 billion people rely on biomass (i.e., wood, charcoal or plant residues) for cooking and heating. In the absence of alternatives, rural people face severe consequences from the overuse of biomass: exposure to smoke from traditional cook stoves and open fires causes more than 1.5 premature deaths annually, with women and young children the most affected. Furthermore, people lose time and money by collecting and purchasing wood and the environment suffers from depletion of natural forests [3].

\section{Materials and Methods}

Pine needles for gasification were collected from the seven sites in Uttrakhand and tested for chemical and physical properties. Chemical tests were performed at The Energy and Resource Institute (TERI) and Jawaharlal Nehru University (JNU) laboratories. Field work on gasifiers was conducted at the Chanderpur Works Private Limited (Yamunanagar) and TERI (Gurgaon) in Haryana. The schedule of parallel testing of $60 \mathrm{hrs}$ and $40 \mathrm{hrs}$ in Yamunanagar and Gurgaon was adopted for those sites, respectively. The industrial-based Kirloskar Green CNG Engine, SL 9o TA series, and the modified Kirloskar RV 3 series, generator sets have been used.

\section{Biomass Types}

Biomass is a term for all organic material that comes from plants, including algae, trees, and crops. Biomass is produced by green plants that convert sunlight into plant material through photosynthesis, and includes all land and water-based vegetation, as well as all organic wastes. Biomass resources can be considered as organic matter, in which the energy of sunlight is stored in chemical bonds. Biomass has always been a major source of energy.

Biomass types can be defined in many different ways, but one simple method is to define as either:

1 Plant Derived 


\section{Animal Derived}

Plant derived biomass resources can be further divided into woody and non-woody biomass. Woody biomass includes trees and tree residues, and energy plantation, etc., while non-woody biomass includes agricultural residues, aquatic, and marine plants, etc. On the other hand, animal-derived biomass can be considered as municipal solid waste, sludge Animalderived biomass, in general, is not used for gasification purposes and, therefore, their characteristic properties have not been studied.

\section{Properties of Biomass}

Each type of biomass has specific properties that determine its performance as a fuel in combustion, or gasification devices, or both. The most important properties relating to the thermal conversion are discussed below.

\section{Moisture Content}

The moisture content of biomass is the quantity of water present in the biomass. The moisture content affects the value of biomass as a fuel. This is particularly important because biomass materials exhibit a wide range of moisture content (on a wet basis), ranging from less than 10 per cent for cereal grain straw up to 50 to 70 per cent for forest residues.

\section{Ash Content}

The chemical breakdown of a biomass fuel, by either thermo-chemical or bio-chemical processes, produces a solid residue. When produced by combustion in air, this solid residue is called 'ash'. The ash content of biomass affects both the handling and processing costs of the overall biomass energy conversion cost. Dependent on the magnitude of the ash content, the available energy of the fuel is reduced proportionately. In a thermochemical conversion process, the chemical composition of the ash can present significant operational problems. This is especially true for combustion processes, where the ash can react to form a 'slag', a liquid phase formed at elevated temperatures, which can reduce plant throughput, and result in increased operating costs.

\section{Volatile Matter and Fixed Carbon content}

The volatile matter (VM) of a solid fuel is that portion which is driven-off as a gas (including moisture) by heating, and the fixed carbon content (FC) is the mass remaining after the releases of volatiles, excluding ash, and moisture contents. These two parameters are important to analyze as in solid fuels chemical energy is stored in two forms, fixed carbon and volatiles. Fuel analysis based upon the VM content, ash, and moisture, with the FC determined by difference, is termed as the proximate analysis of a fuel.

\section{Calorific Value}

The calorific value (CV) of a material is an expression of the energy content, or heat value released when burnt in air. The CV is usually measured in terms of the energy content per unit mass, or volume; hence $\mathrm{MJ} / \mathrm{kg}$ for biomass.

The CV of a fuel can be expressed in two forms, the gross caloric value (GCV) or higher heating value (HHV), and the net caloric value (NCV) or lower heating value (LHV). The HHV is the total energy content released when the fuel is burnt in air including the latent heat contained in the water vapor, and therefore, represents the maximum amount of energy potentially recoverable from a given biomass source. In practical terms, the latent heat contained in the water vapor cannot be used effectively and, therefore, the LHV is the appropriate value to use for the energy available for subsequent use.

\section{Bulk Density}

An important characteristic of biomass materials is their bulk density, or volume, both as produced, and as-subsequently processed. The importance of the asproduced bulk density is in relation to transport, and storage costs. The density of the processed product impacts fuel storage requirements, the sizing of the materials handling system, and how the material is likely to behave during subsequent thermo chemical/ biological processing as a fuel/feedstock. Bulk density is basically an extrinsic property that depends on manner of material handling.

\section{Chemistry of Gasification \\ Drying}

Biomass fuels usually contain moisture in range of 10 and $35 \%$. When the biomass is heated to around $100^{\circ} \mathrm{C}$, the moisture is converted to steam.

\section{Pyrolysis}

After drying after biomass is heated, it undergoes pyrolysis. Pyrolysis is the thermal decomposition of biomass fuels in the absence of oxygen. Biomass decomposes into solid charcoal, liquid tars, and gases.

\section{Oxidation}

Air is introduced in a gasifier in the oxidation zone. In oxidation, taking place at about $700-1400^{\circ} \mathrm{C}$, the solid carbonized fuel reacts with oxygen in the air producing carbon dioxide, and releasing heat.

$$
\mathrm{C}+\mathrm{O} 2=\mathrm{CO} 2+393800 \mathrm{~kJ} / \mathrm{kg}
$$

\section{Reduction}

At higher temperatures, and under reducing conditions, the following reactions take place resulting in formation of $\mathrm{CO}, \mathrm{H}_{2}$, and $\mathrm{CH}_{4}$.

$$
\begin{aligned}
& \mathrm{CO} 2+\mathrm{C}-2 \mathrm{CO}-172600 \mathrm{~kJ} / \mathrm{kg} \text { mole } \\
& \mathrm{C}+\mathrm{H} 2 \mathrm{O}-\mathrm{CO} 2+\mathrm{H} 2-131400 \mathrm{~kJ} / \mathrm{kg} \\
& \mathrm{CO} 2+\mathrm{H} 2 \mathrm{O}-\mathrm{CO} 2+\mathrm{H} 2+41200 \mathrm{~kJ} / \mathrm{kg} \text { mole } \\
& \mathrm{C}+2 \mathrm{H}_{2}-\mathrm{H}_{4}+7500 \mathrm{~kJ} / \mathrm{kg} \mathrm{mol}
\end{aligned}
$$




\section{Downdraft or Co-Current Gasifier}

In the downdraft gasifier, or co-current type, the pyrolysis zone is above the combustion zone, and the reduction zone is below the combustion zone (figure 1). Fuel is fed from the top. The flow of air is downward through the combustion and reduction zones. The term co-current refers to the fact that the movement of air is in the same direction as that of the fuel. The essential characteristic of the downdraft gasifier is that it is designed in such a way that the tars given off in the pyrolysis zone travels through the combustion zone where they will be broken down or burned. As a result, energy is released, and the mixture of gases in the exit stream is relatively clean. The arrangement of combustion zone is thus a critical element in the downdraft gasifier. Downdraft gasifiers are used mostly in power applications.

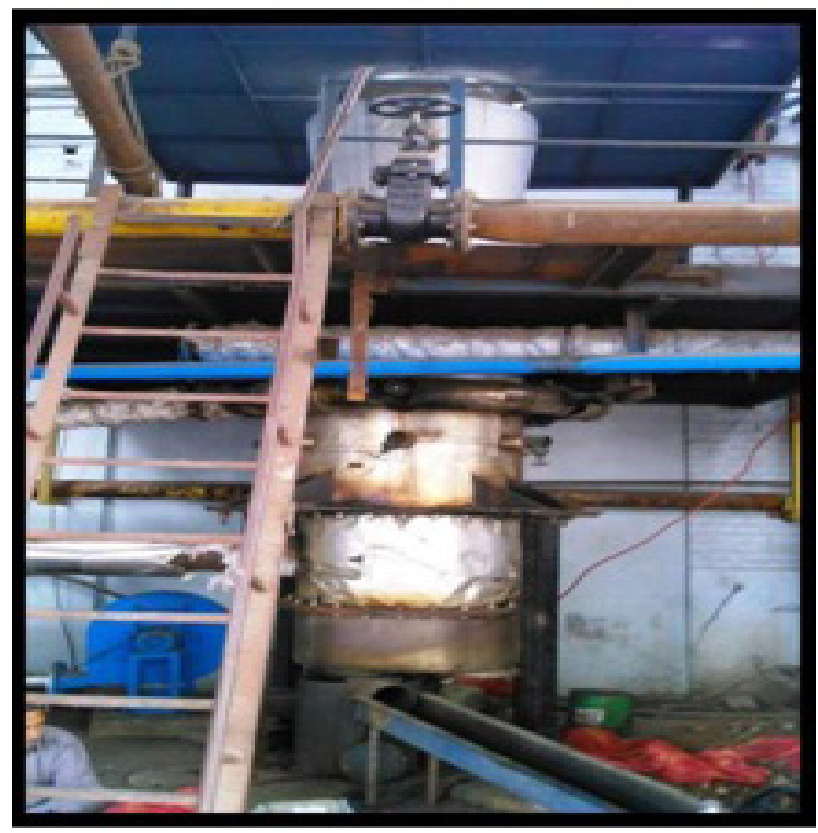

Figure 1: Downdraft gasifier (throat-less) for wood at the Chanderpur works

\section{Stratified Downdraft Gasifier}

The throat-less (startified or open top) downdraft gasifier was developed to overcome the problem of bridging and channeling in throated (Imbert) downdraft gasifiers (figure 2). The gasifier consists of a cylindrical vessel with a hearth at the bottom. During operation, the air and biomass move downwards through the four zones in the reactor.

The open top ensures uniform access of air and permits fuel to be fed easily and uniformly, which keeps the local temperatures in control. The hot producer gas generated is drawn below the grate and up through the annulus of the reactor, where a part of the heat of the gas is transferred to the cold fuel entering the reactor, improving the thermal efficiency of the system. The pyrolysis components are cracked in the oxidation zone, as gas traverses a long uniformly arranged bed of hot char without any low temperature zones, therefore the tar generated is low $0.05 \mathrm{~kg}$ tar $/ \mathrm{kg}$ gas. The open top throat-less gasifier is suitable for small sized biomass having high ash content up to $20 \%$.The gasifier is easy to construct and has good scale up properties [1].

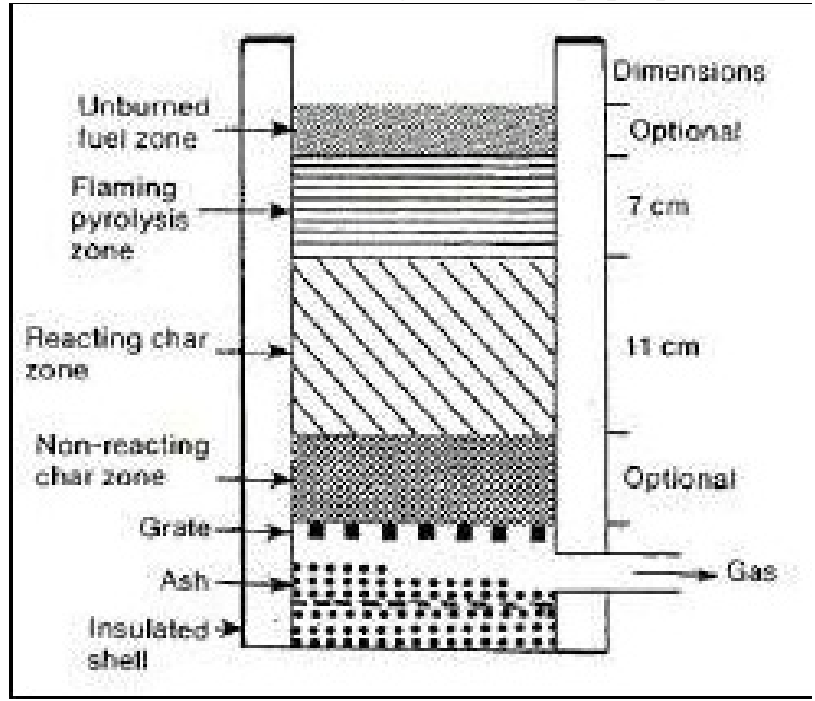

Figure 2: Stratified Downdraft Gasifier

\section{Non-Isokinetic Sampling}

For high-temperature $\left(>350^{\circ} \mathrm{C}\right)$ sampling, where the tar is completely in gas phase, non-isokinetic sampling is sufficient for measuring tar. In non-isokinetic sampling the alignment of the probe in relation to the gas flow as well as the shape of the probe nozzle can be designed more freely to prevent the nozzle from blocking. This is important especially during pressurized operation since the probe cannot be removed from the gas line. The end of the probe must point against the direction of the gas stream (figure 3). The tip of the nozzle can be straightended or $45^{\circ}$ angled.

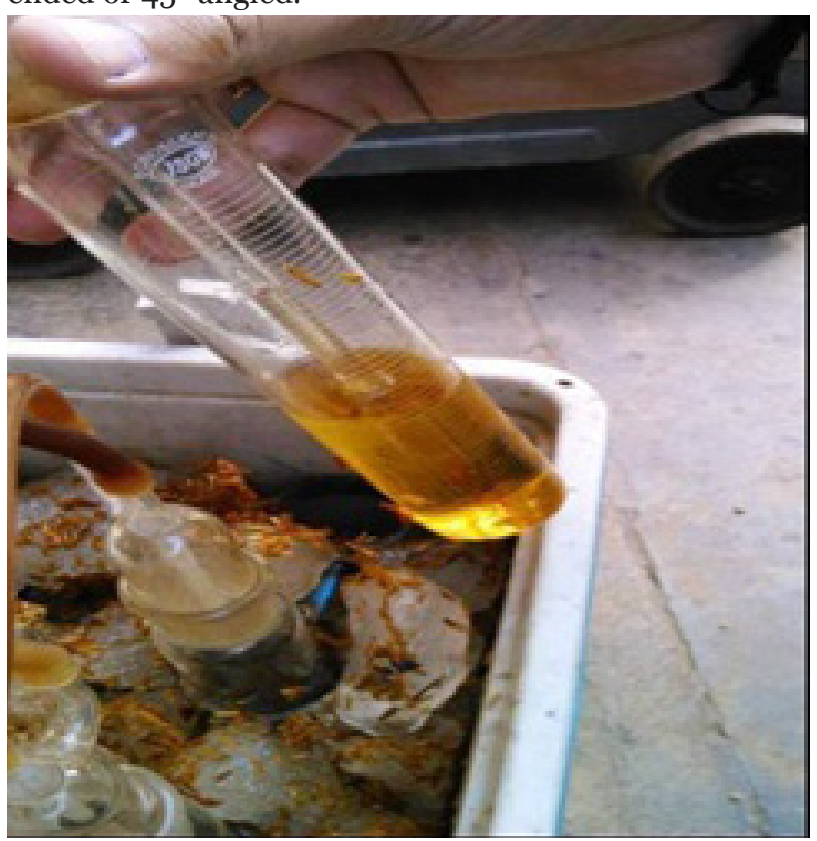

Figure 3: Tar content in an impinger bottle

\section{Combustion and flue analysis}

Combustion analysis is part of a process intended 


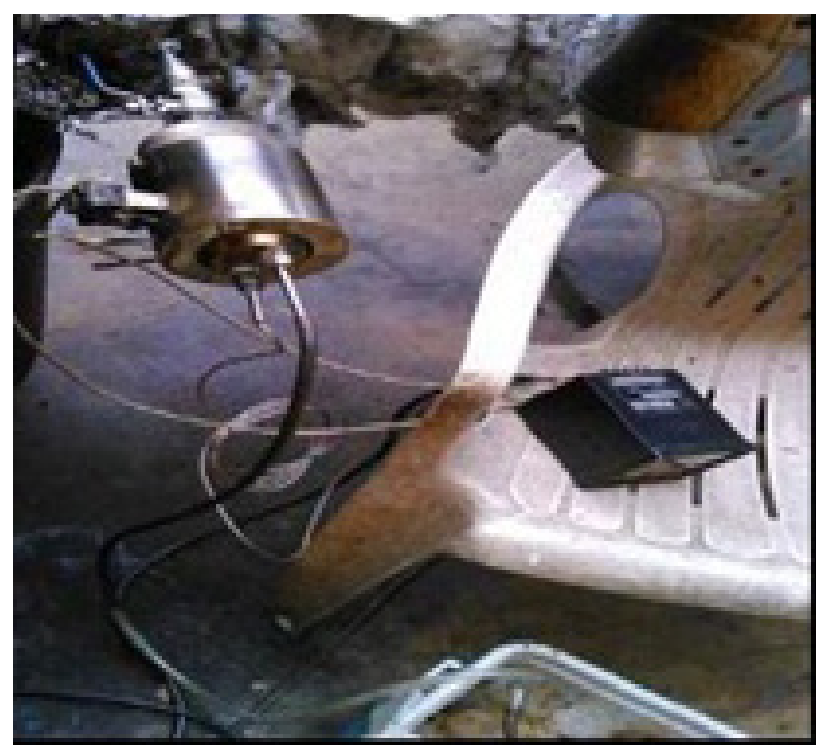

Figure 4: Separator and the temperature controller

to improve fuel economy, reduce undesirable exhaust emissions, and improve the safety of fuel burning equipment. Combustion analysis begins with the measurement of flue gas concentrations and gas temperature, and may include the measurement of draft pressure and soot level [7].

Heat loss due to dry gas $(\mathrm{Lg})$

$\mathrm{Lg}=\mathrm{Wg} \times \mathrm{Cp} \times\left(\mathrm{T}_{\text {flue }}-\mathrm{T}_{\text {supply }}\right)$

(Where: $\mathrm{Wg}=$ the weight of the flue gases per pound of as-Fired fuel)

$\mathrm{Cp}=$ specific heat of the exhaust gas mix.

$\mathrm{T}_{\text {flue }}=$ flue temperature

$\mathrm{T}_{\text {supply }}=$ combustion supply air temperature.

Heat loss due to $\mathrm{H} 2 \mathrm{O}$ from combustion of hydrogen ( $\mathrm{Lh}$ ) Where the fuel has high hydrogen content, latent heat loss from the water formation can be very significant.

$\mathrm{Lh}=8.936 \times \mathrm{H} \mathrm{x}\left(\mathrm{h}_{1}-\mathrm{h}_{\mathrm{rw}}\right)$

Where: 8.936 = weight of water formed for each hydrogen atom $\mathrm{H}=$ fractional hydrogen content of the fuel

$\mathrm{h}_{1}=$ enthalpy of water at the exhaust temperature and pressure $h_{\mathrm{rw}}=$ enthalpy of water as a saturated liquid at fuel supply temperature

\section{Heat loss due to moisture in fuel $\left(L_{m}\right)$}

Moisture in the fuel is determined from lab analysis of the fuel and can be obtained from the fuel.

$\mathrm{Lm}=$ fraction fuel moisture $\mathrm{x}\left(\mathrm{h}_{1}-\mathrm{h}_{\mathrm{rw}}\right)$

Where: $h_{1}=$ enthalpy of water at exit gas temperature and pressure

$\mathrm{h}_{\mathrm{rw}}=$ enthalpy of water at fuel supply temperature

\section{Heat loss due from the formation of carbon monoxide} $\left(L_{c o}\right)$

Carbon in the fuel reacts with oxygen to form CO first, then $\mathrm{CO} 2$, are generating a total of 14,540 Btus of heat per pound of carbon. If the reaction stops at $\mathrm{CO}$ because of insufficient $\mathrm{O} 2$ or poor mixing of fuel and air, 10,160 Btus of energy are lost.

$\mathrm{L}_{\mathrm{CO}}=\left[\% \mathrm{CO} /\left(\% \mathrm{CO}+\% \mathrm{CO}_{2}\right)\right] \times 10719.367 \times$ Carbon content of fuel

\section{Combustion Efficiency}

Combustion efficiency is expressed as a percent and determined by subtracting individual stack heat losses, as percents of the fuel's heating value, from the total heating value of the fuel (100\%). Dry gas loss and latent heat loss due to $\mathrm{H} 2$ in the fuel are typically the largest sources of stack loss. Others can be included, such as heat loss from moisture in the air and fuel and losses from the formation of $\mathrm{CO}$ rather than $\mathrm{CO} 2$.

\%Net Combustion Efficiency $=100$ - flue heat losses/ fuel heating value $/ \mathrm{kg}$ fuel

Flue heat losses $=\mathrm{L}_{\mathrm{g}}+\mathrm{L}_{\mathrm{h}}+\mathrm{L}_{\mathrm{m}}+\mathrm{L}_{\mathrm{co}}$ (Individual heat losses are described in this section.)

Where: $\mathrm{L}_{\mathrm{g}}=$ heat loss due to dry gas

$\mathrm{L}_{\mathrm{h}}=$ heat loss due to moisture from burning hydrogen $(\mathrm{kJ} / \mathrm{kg})$

$\mathrm{L}_{\mathrm{m}}=$ heat loss due to moisture in fuel $(\mathrm{kJ} / \mathrm{kg})$

$\mathrm{L}_{\mathrm{co}}=$ heat loss from the formation of $\mathrm{CO}(\mathrm{kJ} / \mathrm{kg})$

\%Gross Combustion Efficiency $=100-\mathrm{Lg} /$ fuel heating value $/ \mathrm{kg}$ fuel

\section{Excess air}

Insufficient combustion air causes a reduction in fuel efficiency, creates highly toxic carbon monoxide gas, and produces soot. To ensure there is enough oxygen to completely react with the fuel, extra combustion air is usually supplied. This extra air, called "Excess Air," is expressed as the percent air above the amount theoretically needed for complete combustion.

$\%$ Excess air $=\left(\% \mathrm{O} 2_{\text {measured }} / 20.9-\% \mathrm{O} 2_{\text {measured }}\right) \times 100$

Or

$\%$ Excess air $=\left(\mathrm{O}_{2}-0.5 \mathrm{CO} / 0.2682 \mathrm{~N} 2-(\mathrm{O} 2-\right.$ $0.5 \mathrm{CO})) \mathrm{x} 100$

\section{Equivalence Ratio}

Ratio of actual A/F to stoichiometric A/F is known as equivalence ratio

$$
\Phi=(\text { Actual A/F)/ (Stoichiometric A/F) }
$$

\section{$H$ Instrumentation}

\section{Junker Calorimeter}

The Junker calorimeter is a device for measuring the heating capacity of a gas only (figure 5). The calorimeter is fixed upon a tripod stand, having leveling screws to keep the calorimeter in perfectly vertical position. The calorimeter mainly consists of a gas combustion chamber, a heat exchanger and the water flow system. Heat exchanger is designed for the maximum efficiency of heat exchanger, fabricated out of heavily tinned copper sheet.

\section{Online Gas Analyzer}

An online gas analyzer (figure 6) is an instrument 


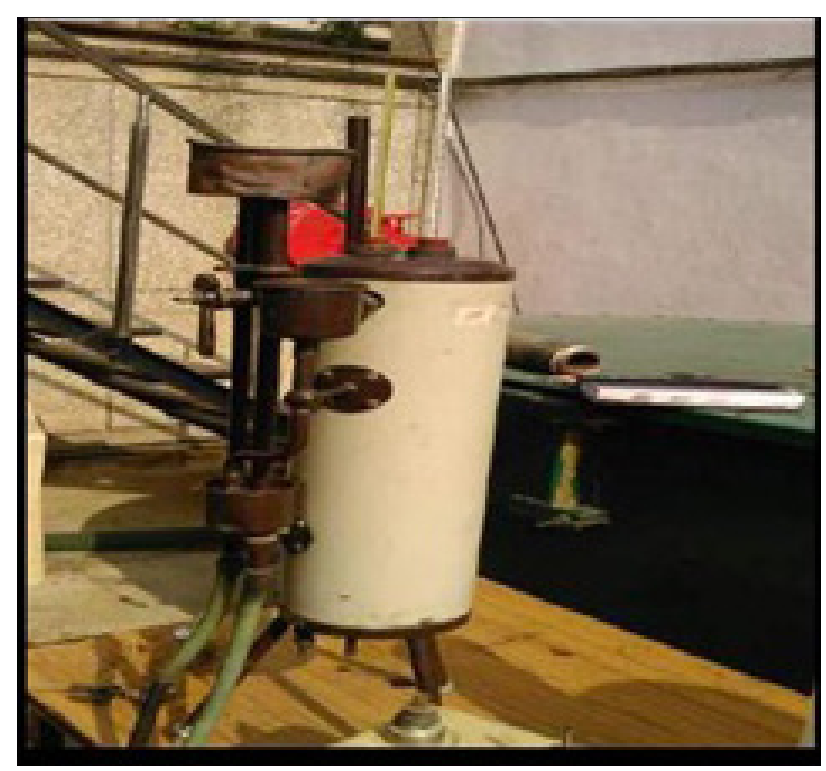

Figure 5: Junker calorimeter

used for determining the composition of producer gas stream, and gives instantaneous values, unlike other sampling methods which take a long time to give the composition values.

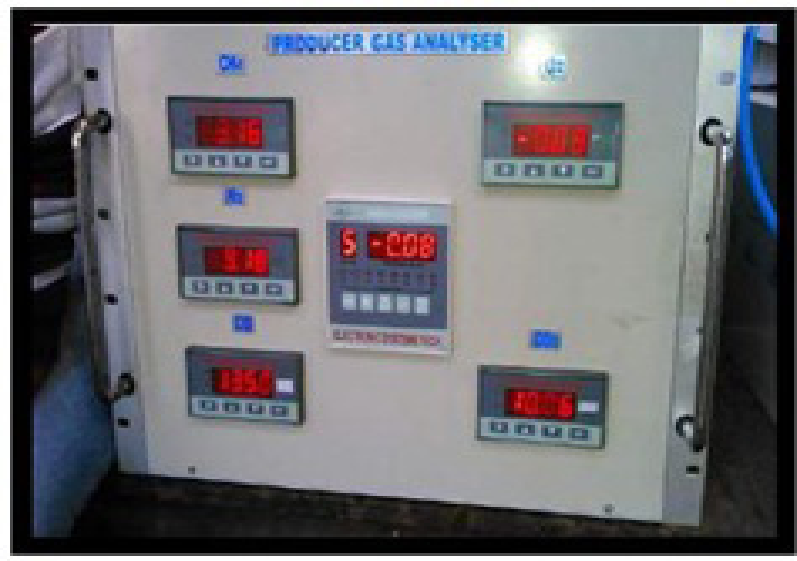

Figure 6: Online gas analyzer

\section{CHN/O Analyzer}

For the determination of carbon, hydrogen, nitrogen, and oxygen, the ultimate analysis of biomass and oil samples is done using the $\mathrm{CHN} / \mathrm{O}$ analyzer (figure 7).

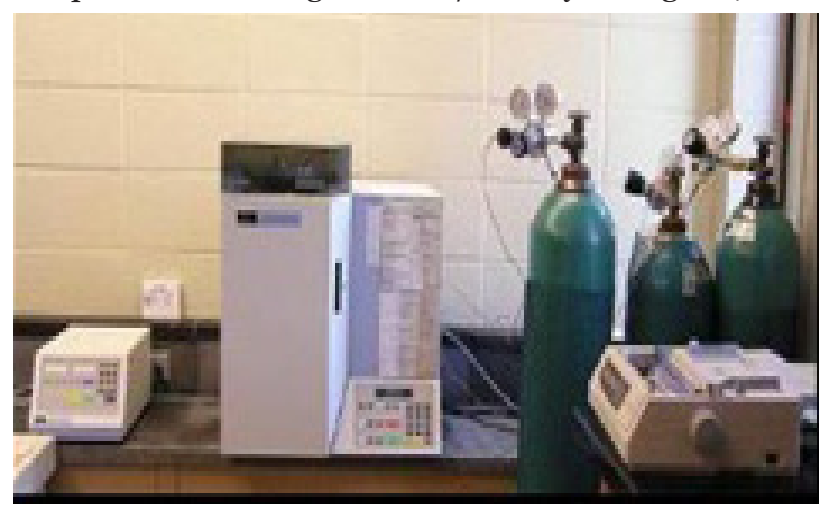

Figure 7: $\mathrm{CHN} / \mathrm{O}$ analyzer

Hot-Wire Anemometer

A hot-wire anemometer is used to measure the speed of producer gas flowing outside the tuyere or nozzle. It uses a very fine wire (on the order of several micrometers) electrically heated to some temperature above the ambient. Air flowing past the wire has a cooling effect on the wire. As the electrical resistance of most metals is dependent upon the temperature of the metal, a relationship can be obtained between the resistance of the wire and the flow speed.

\section{Results and Discussion}

Besides chemical analysis of pine needles, some biomass properties such as bulk density, energy density, and higher heating value were also evaluated in due course of experimentation. The prime assessment of pine needles provides a broader perspective to evaluate the performance characteristic of the throat less gasifiers. After completion of flue analysis that includes composition and stoichiometric calculation of producer gas, combustion analysis of the gasifier has been conducted.

\section{Chemical Analysis}

Before testing pine needles in a throat less gasifier, we have chemically examined the eight samples collected from the seven different places in Uttrakhand to know the chemical composition of the given substrates. Ultimate analysis and proximate analysis provide us the valuable data about $\mathrm{H} / \mathrm{C}$ and $\mathrm{O} / \mathrm{C}$ in order to determine the viability of pine needles as an alternative source for power generation in hamlets.

\section{Ultimate Analysis}

Ultimate analysis of coal and coke is defined in ASTM D 3176 as the determination of the carbon and hydrogen in the material, as found in the gaseous products of its complete combustion, the determination of sulphur, nitrogen, and ash in the material as a whole, and the estimation of oxygen by difference. The ultimate analysis of pine needles is laid out in table 1.

\begin{tabular}{|c|c|c|c|c|l|c|}
\hline \multirow{2}{*}{$\mathrm{C}(\%)$} & $\mathrm{H}$ & $\mathrm{N}$ & $\mathrm{O}$ & $\mathrm{S}$ & Moisture & Ash \\
\cline { 2 - 7 } & $(\%)$ & $(\%)$ & $(\%)$ & $(\%)$ & $(\%)$ & $(\%)$ \\
\hline 53.66 & 5.52 & 0.59 & 32.56 & 0.2 & 4.02 & 3.44 \\
\hline
\end{tabular}

Table 1: Ultimate analysis of Pine Needle

\section{Proximate Analysis}

Proximate analysis is use to determine the approximate amount of substances within a material. The process of proximate analysis is complicated and often involves either extraction or remote sensing to determine the varying amount of substances within one material, though different methods are used for different materials. This information can be used to create quality controls for various materials, ensure that they do not contain hazardous chemicals, and determine whether they are healthy enough to be consumed by humans or animals. The size of the sample and the methods for readying the sample vary depending on the type of material being analyzed. Once the material 
has been readied, the sample is analyzed using one of a few recognized techniques. Extraction is a means of utilizing additional substances and chemicals to bring certain substance out of the material so that they can be examined and measured.

After the sample has been analyzed using one of these techniques, an analysis of the components can be done. Analysis is performed using both qualitative and quantitative techniques to form measurements. The precise instruments used for analysis depend on the sample being tested and the result.

\begin{tabular}{|l|c|c|c|}
\hline $\begin{array}{c}\text { Volatile } \\
\text { Matter (\%) }\end{array}$ & $\begin{array}{c}\text { Fixed } \\
\text { carbon } \\
(\mathbf{\%})\end{array}$ & $\begin{array}{c}\text { Moisture } \\
(\mathbf{\%})\end{array}$ & $\begin{array}{c}\text { Ash } \\
\text { content } \\
(\mathbf{\%})\end{array}$ \\
\hline 66.73 & 16.01 & 15.03 & 2.238 \\
\hline
\end{tabular}

Table 2: Proximate analysis of pine needle

\section{Calorimetry of Pine Needle}

Calorimetry is the science of measuring quantities of heat, as distinct from "temperature". The instruments used for such measurements are known as calorimeters [2]. Heating value of biomass is one of the major parameters that must be known so that we can determine the other related parameters of pine needles. Bomb calorimeters have been used to determine the heating value of pine needles. The calorific value or heating value, or energy value, or heat of combustion of a sample can be broadly defined as the number of heat units liberated by a unit mass of a sample when burned with oxygen in an enclosure of constant volume. In this reaction, the sample and the oxygen are initially at the same temperature and the products of combustion are cooled to within a few degrees of the initial temperature; also the water vapour formed by the combustion is condensed to the liquid state.

\begin{tabular}{|c|c|c|c|}
\hline $\begin{array}{c}\mathbf{H H V}_{\mathrm{v}} \\
\text { (dry basis) } \\
\text { (MJ/kg) }\end{array}$ & $\begin{array}{c}\mathbf{H H V}_{\mathrm{p}} \\
(\mathbf{d r y} \text { basis) } \\
\text { (MJ/kg) }\end{array}$ & $\begin{array}{c}\text { HHV }_{\mathrm{v}} \\
\text { (moist basis) } \\
\text { (MJ/kg) }\end{array}$ & $\begin{array}{c}\mathbf{H H V}_{\mathrm{p}} \\
(\mathbf{m o i s t} \text { basis) } \\
\text { (MJ/kg) }\end{array}$ \\
\hline 19.45 & 19.44 & 18.67 & 18.66 \\
\hline
\end{tabular}

Table 3: High heating value of pine needles at constant pressure and volume

\section{Calorimetry of Producer Gas}

Calorimetry of producer gas has been conducted in a similar manner to the means for determining the calorific value of pine needles. The values are shown in table 5 .

\begin{tabular}{|c|c|}
\hline $\mathrm{HHV}_{\mathrm{V}}$ & $\mathrm{LHV}_{\mathrm{v}}$ \\
\hline$\left(\mathrm{MJ} / \mathrm{m}^{3}\right)$ & $\left(\mathrm{MJ} / \mathrm{m}^{3}\right)$ \\
\hline 3.867 & 3.580 \\
\hline
\end{tabular}

Table 4: Low heating value of pine needles at constant pressure and volume

\section{Flue gas Analysis}

A gasifier in which heat is produced by the partial combustion of biomass can be considered to have fuel and combustion air as input, and producer gas, as the output. Generally, the biomasses are the derivatives of either plants or animals, which are lingo cellulosic in nature. Biomasses are not readily burned to form

\begin{tabular}{|c|c|c|c|}
\hline $\begin{array}{c}\mathrm{LHV}_{\mathrm{v}} \\
\text { (dry basis) } \\
(\mathrm{MJ} / \mathrm{kg}) \\
\end{array}$ & $\begin{array}{c}\mathrm{LHV}_{\mathrm{p}} \\
\text { (dry basis) } \\
\text { (MJ/kg) } \\
\end{array}$ & $\begin{array}{l}\mathrm{LHV}_{\mathrm{v}} \\
\text { (moist } \\
\text { basis) } \\
\text { (MJ/kg) }\end{array}$ & $\begin{array}{c}\mathrm{LHV}_{\mathrm{p}} \\
\text { (moist } \\
\text { basis) } \\
\text { (MJ/kg) }\end{array}$ \\
\hline 19.35 & 19.34 & 18.57 & 18.56 \\
\hline
\end{tabular}

Table 5: Calorific value of producer gas

carbon monoxide, or a mixture of carbon monoxide and carbon dioxide, as moisture content in biomass increases the sensible heating of biomass that doesn't allow it to undergo oxidation in the presence of less air that is required for oxidation. Here in gasification, air required is always less than stoichiometric air,unlike the combustion in engine, where stoichometric varies accordingly to the engine operating stages viz. idling, crusing, and power ranges. Air contains nitrogen as well as oxygen and water vapor, but the ambient temperature is very high that make the moist air almost dry. The nitrogen does not take part in combustion process and we obtain it in diluted form at the output end.

\section{Composition of Producer Gas}

Composition of producer gas mainly depends upon the availability of air flow inside the gasifier. As the percentage of oxygen in air goes down, the carbon monoxide level goes up. A producer gas analyzer has been used to calculate the instantaneous value of composition of producer gas with time.

Practically, the oxygen level is kept zero in producer gas, but the producer gas analyzer displayed a negative value of oxygen in our flue gas sampling. To produce a richer composition in our sample, the air percentage should be sufficient to undergo complete combustion. Inhibition of the complete combustion and the better reduction provides us the rich mixture of carbon monoxide, methane, and hydrogen. However, the nitrogen percentage remains the same throughout the gasification process (table 6).

\begin{tabular}{|l|l|l|l|c|}
\hline $\mathbf{C O}(\mathbf{\%})$ & $\mathbf{H}_{\mathbf{2}} \mathbf{( \% )}$ & $\mathbf{C H}_{\mathbf{4}} \mathbf{( \% )}$ & $\mathbf{C O}_{\mathbf{2}} \mathbf{( \% )}$ & $\mathbf{N}_{\mathbf{2}} \mathbf{( \% )}$ \\
\hline 14 & 10.59 & 2.378 & 14 & 59.03 \\
\hline
\end{tabular}

Table 6: Final composition of producer gas

\section{Stoichiometric Analysis}

Stoichiometric or chemically correct air is the minimum amount of air required for the complete combustion of pine needles into product of combustion (i.e., the whole carbon will convert carbon dioxide and hydrogen into water). The final temperature of the product of combustion will reach to the pre-combustion temperature so that latent heat of water can be added to our higher heating value. Conversely, gasification doesn't require stoichiometric air to carry out the combustion reaction completely. After decomposition of hydrocarbon, the carbon reacts with supplying air so as to form the carbon dioxide, but the insufficient moles of oxygen prevent the reaction from proceeding further. Ultimately, the incomplete combustion results in carbon monoxide. It is, however, not necessary to obtain 100\% carbon monoxide. Some moles of carbon converted into 
carbon dioxide subsequently reduce to methane while undergoing reduction at the last stage of gasification process.

\begin{tabular}{|c|c|c|c|c|}
\hline 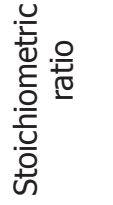 & 苞 & 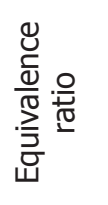 & 蒿 & $\begin{array}{l}\frac{4}{0} \\
\frac{3}{\square} \cdot \frac{1}{\pi}\end{array}$ \\
\hline $\mathrm{A} / \mathrm{F}$ & $\mathrm{A} / \mathrm{F}$ & $\varphi$ & $(\%)$ & $\left(\mathrm{m}^{3} / \mathrm{hr}\right)$ \\
\hline 6.649 & 6.239 & 0.93 & -41 & 182 \\
\hline
\end{tabular}

Table 7: Stoichiometric analysis of Gasifier

\section{Tar and Dust Sampling}

Tar (table 8) is one of the most unpleasant constituents of the gas as it tends to deposit on the surface of the throttle body and the intake valves of engine, which reduce the running hours of our engine parts. It results due to an irreversible process taking place during pyrolysis inside the gasifier. The physical property of tar depends upon temperature and heat rate and the appearance ranges from brown and watery $(60 \%$ water) to black and highly viscous ( $7 \%$ water). There are approximately 200 chemical constituents that have been identified in tar so far.

All gasifier fuels produce dust (table 9). Dust is an unwanted product that should be minimized along with tar content since it has detrimental effect on the performance of engine parts. Dust gets clogged inside the engine block and reduces the lifespan of engine liners. The gasifier design should be such that it does not produce more than $2-6 \mathrm{~g} / \mathrm{m}^{3}$ of dust.

\begin{tabular}{|c|c|c|c|c|}
\hline $\begin{array}{c}\text { Weight of } \\
\text { flask } \\
\text { (gram) }\end{array}$ & $\begin{array}{c}\text { Weight of } \\
\text { flask and tar } \\
\text { (gram) }\end{array}$ & $\begin{array}{c}\text { Weight } \\
\text { of tar } \\
(\mathrm{mg})\end{array}$ & $\begin{array}{c}\text { Flow of } \\
\text { gas in an } \\
\text { hour } \\
\left(\mathrm{m}^{3} / \mathrm{hr}\right)\end{array}$ & $\begin{array}{c}\text { Tar } \\
\text { content } \\
\left(\mathrm{mg} / \mathrm{m}^{3)}\right.\end{array}$ \\
\hline 112.35533 & 112.389549 & 34.2197 & 0.739 & 46.3054 \\
\hline
\end{tabular}

Table 8: Tar testing during gasification

\section{Combustion Analysis}

\section{Calculating the Carbon Dioxide Concentration}

Carbon dioxide $(\mathrm{CO} 2)$ forms when carbon in the fuel combines with $\mathrm{O} 2$ in the combustion air (table 10). When there is enough $\mathrm{O} 2$ to react with the carbon in the fuel, the $\mathrm{CO} 2$ concentration in the stack exhaust is at its highest level. This is generally at or close to the ideal operating condition for heat generating equipment.

\begin{tabular}{|l|l|l|l|l|}
\hline $\begin{array}{c}\text { Type of } \\
\text { sample }\end{array}$ & $\begin{array}{c}\text { Flow of } \\
\text { gasin an } \\
\text { hour }\left(\mathrm{m}^{3} /\right. \\
\mathrm{hr})\end{array}$ & $\begin{array}{c}\text { Dust } \\
\text { content } \\
\text { collected } \\
\text { in an hour } \\
\text { (gram/hr) }\end{array}$ & $\begin{array}{c}\text { Dust } \\
\text { content } \\
\left(\mathrm{mg} / \mathrm{m}^{3}\right)\end{array}$ & $\begin{array}{c}\text { Dust } \\
\text { content } \\
\text { in }(\mathrm{ppm})\end{array}$ \\
\hline Clean gas & 0.739 & 0.0242 & 32.7 & 0.0327 \\
\hline Raw gas & 0.739 & 0.0928 & 125.5 & 0.1255 \\
\hline Clean gas & 0.739 & 0.01 & 13.5 & 0.0135 \\
\hline Raw gas & 0.342 & 0.07516 & 219.766 & 0.2197 \\
\hline
\end{tabular}

Table 9: Dust content testing during running hours

\begin{tabular}{|c|c|c|}
\hline $\begin{array}{c}\mathrm{CO}_{2} \text { (maximum) } \\
(\%)\end{array}$ & $\begin{array}{c}\mathrm{CO}_{2} \text { (maximum) } \\
(\mathrm{ppm})\end{array}$ & $\begin{array}{c}\text { Calculated in } \\
\text { gasification }\end{array}$ \\
\hline 15.46 & 154600 & $12.8 \%$ \\
\hline
\end{tabular}

Table 10: Maximum and calculated value of Carbon dioxide

\section{Combustion Efficiency of the Downdraft Gasifier}

Combustion efficiency (table 11) is expressed as a percentage and determined by subtracting individual stack heat losses as a percentage of the fuel's heating value, from the total heating value of the fuel (100\%). Dry gas loss and latent heat loss due to $\mathrm{H} 2$ in the fuel are typically the largest sources of stack loss. Others can be included, such as heat loss from moisture in the air and fuel and losses from the formation of $\mathrm{CO}$ rather than $\mathrm{CO} 2$ [7].

\begin{tabular}{|l|l|l|}
\hline \multirow{2}{*}{$\begin{array}{l}\text { D o w n d raft } \\
\text { Gasifier }\end{array}$} & $\begin{array}{l}\eta_{\text {gross }} \\
(\%)\end{array}$ & $\begin{array}{l}\eta_{\text {net }} \\
(\%)\end{array}$ \\
\cline { 2 - 3 } & 97.13 & 76.66 \\
\hline
\end{tabular}

Table 11: Combustion Efficiency of downdraft gasifier while using pine needles

\section{Losses in the Downdraft Gasifier}

Losses in gasifier indicates the heat loss due to dry gas, the heat loss due to moisture, the heat loss due to the formation of $\mathrm{H}_{2} \mathrm{O}$ from the combustion of $\mathrm{H}_{2}$, the radiation and conduction loss, and the heat loss from the formation of $\mathrm{CO}$ (table 12; figures 8 and 9). Heat loss due to moisture in engine is considered due to be zero since gas is almost in dry state.

\begin{tabular}{|c|c|c|c|c|c|c|}
\hline 9 & $f$ & $\xi$ & 8 & $\underline{q}$ & 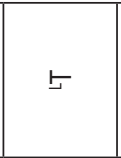 & 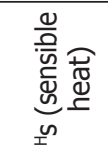 \\
\hline$(\mathrm{kJ} / \mathrm{kg})$ & $(\mathrm{kJ} / \mathrm{kg})$ & $(\mathrm{kJ} / \mathrm{kg})$ & $(\mathrm{kJ} / \mathrm{kg})$ & $(\mathrm{kJ} / \mathrm{kg})$ & $(\mathrm{kJ} / \mathrm{kg})$ & $(\mathrm{kJ} / \mathrm{kg})$ \\
\hline 532.8 & 887.9 & 37.72 & 2875 & 2649 & 6982.42 & 1159 \\
\hline
\end{tabular}

Table 12: Losses occur due to gasification

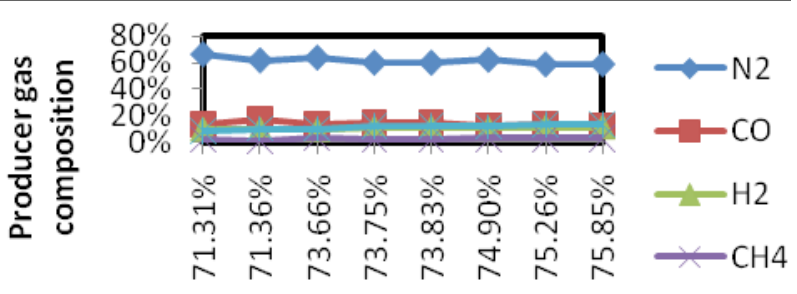

Combustion efficiency of gasifier (iveE( 2

Figure 8: Effect of producer gas composition on combustionfficiency of gasifier (Net)

\section{Energy Diagram (Sankey diagram)}

The Sankey diagram (figure 10) is useful tool to represent an entire input and output energy flow in any energy equipment or system such as boilers, fired heaters, furnaces, and gasifiers. This diagram represents visually outputs and losses so that energy managers canfocus on finding improvements in a prioritized manner. 


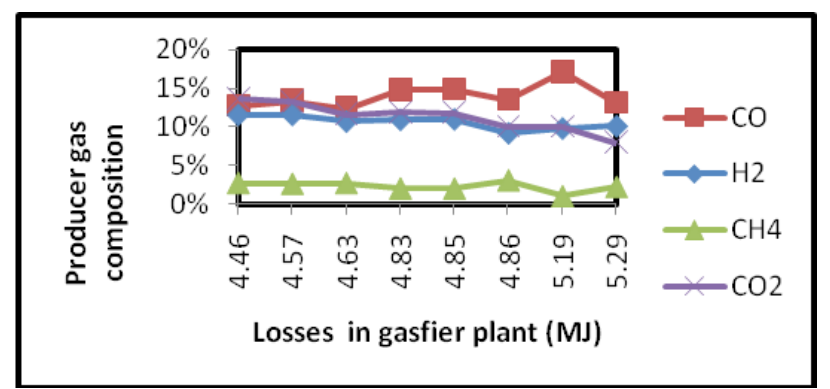

Figure 9: Effect of Producer gas on the losses in gasifier plant

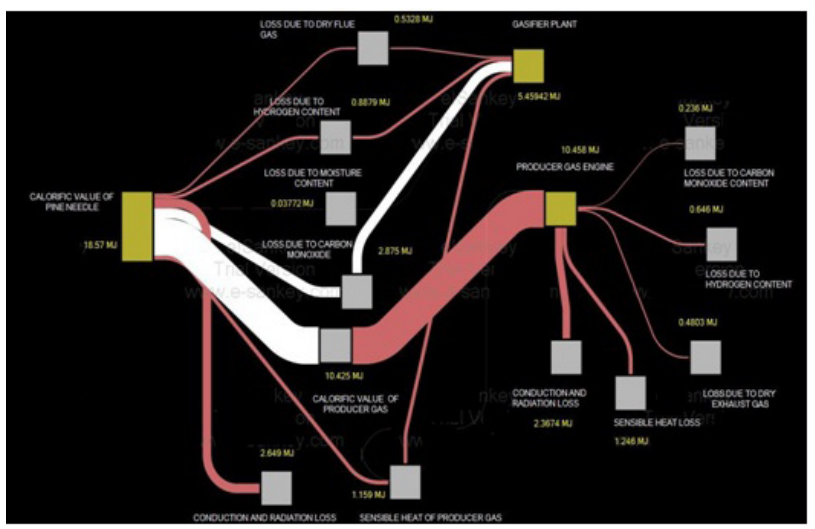

Figure 10: Energy Diagram of the gasifier plant

\section{Ternary Diagram of Pine Needle Gasification}

A Ternary diagram represents the various reactions or the processes takes place within a system. It is used to indicate the phases of given mixtures (figure 11). The three apex of triangle shows $100 \%$ of a component in mixture. As we move away from the apex, the value of a given component decreases by $10 \%$, which is shown by the grid lines. Here in this diagram you can see the various gasification reactions taking place inside the gasifier from drying to reduction stage.

In this diagram, the molar fraction of a pine needle has been used to represent the oxidation process in the open space. The point $\mathrm{M}$ represents pine needles. The line segment $\mathrm{MJ}$ represents reactants side, while the line segment BC, product side, i.e. Carbon dioxide and water. If complete oxidation of pine needles is done in the presence of stoichiometric air, the whole carbon and hydrogen in our biomass would be converted into carbon dioxide and water, which intersect the reactant line at point $\mathrm{I}$, which is an equilibrium point. If complete combustion takes place, the phase of carbon dioxide and water lies on this line, whereas the points lie above the equilibrium point I shows incomplete combustion phase of our biomass. Quadrilateral ABLD shows gasification process of pine needle inside gasifier. Points E, H, B, D, and $\mathrm{L}$ represent $\mathrm{CH}_{4}, \mathrm{CO}, \mathrm{CO} 2, \mathrm{H} 2$, and $\mathrm{H}_{2} \mathrm{O}$ respectively on ternary diagram. The triangle BCJ represents the oxidation process on whose one side equilibrium line segment exist, i.e. $\mathrm{BC}$ (the mixture of $\mathrm{CO}_{2}$ and $\mathrm{H}_{2} \mathrm{O}$ lies on this line). Carbon in $\mathrm{CO}_{2}$ will diluted when moves down from the point $\mathrm{B}$, whereas percentage of oxygen decrease in $\mathrm{CO} 2$ towards up side of the point $\mathrm{B}$. The transition state between the points
$\mathrm{G}$ and I shows conversion of carbon monoxide into carbon dioxide, which can be deterred if the availability of oxygen in air is reduced. The transition state between the points $\mathrm{G}$ and $\mathrm{H}$ shows actual oxidation stage inside gasifier. The slope of line segment LH demarcates the transformation of carbon monoxide into carbon dioxide. A good gasification or higher calorific value of producer gas can be achieved if the oxidation line of biomass juxtapose to the line segment LH. Farther you go below the point $\mathrm{G}$, the poorer will be the gasification, and you will obtain lower calorific value.

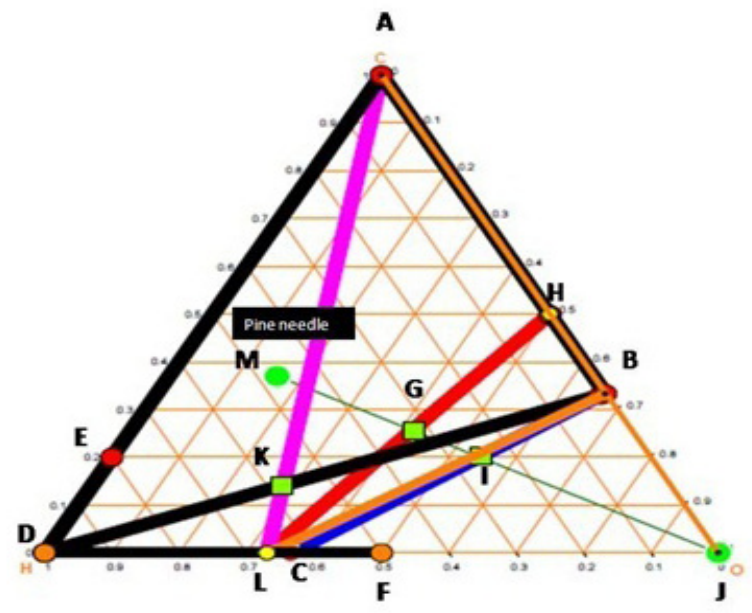

Figure 11: Representation of gasification and oxidation reactions of pine needle on Ternary Diagram

Zone of oxidation state inside gasifier should lie between the points $\mathrm{G}$ and I, but preferably closer to the point $\mathrm{G}$.

$\mathrm{G}<$ Zone of oxidation inside gasifier $<$ I

\section{Feasibility Study}

Feasibility study of a downdraft gasifier is one of preliminary requirement before conducting an experiment in order to install the gasifier unit for power generation in hamlets. The running cost of a gasifier while using pine needles, the environmental factors, and the technical viabilities are some of the points worth noting before carrying out testing.

\section{Cost of Power Generation}

For 100 hours of testing, 5.5 tonnes of pine needles have been consumed at two different sites. Purchasing pine needles in Himanchal Pradesh state is 6.5 Rs per $\mathrm{kg}$ of pine needles, while in Uttrakhand, 1 Rs per $\mathrm{kg}$. However, transportation costs are appreciably high since bulk density of pine needle is less than other fuels, yet it saves 25 to $30 \%$ compared to coal. Biomass consumption of pine needles is $2.2 \mathrm{~kg} / \mathrm{kWh}$. Thus, in our study, the total cost of bringing pine needles from place of source to testing unit is 16252.8 Rs. per tonne. The running cost of downdraft, if using pine needles as a feedstock, is 2.2 Rs per kWh (excluding transportation cost).

\section{Environmental Factors}

Burning of pine needles in an open space causes 
high emissions of carbon monoxide and carbon dioxide. Residual forest waste, which is prolific in the Himalayan region, cannot be used. But for the improvement of mountain regions, where a dearth of power hinders development, pine needles can be used to appreciable benefit. The reduction of carbon dioxide by $2.66 \%$ in Table 10 shows its environmental benefits. Feedstock for animals and underground water level, which are severely affected with pine needles litter, are sort out by using it for gasification purpose.

\section{Technical Feasibility}

Gasifiers are not a constant source of power generation unlike other fuels. Gasifiers require biomass for producer gas generation. Bridging and channeling inside the gasifier can cause constriction while using pine needles, but opting for the right design of a gasifier can solve the problem of constriction and improve power output. Pine needles have a bulk density of $94.33 \mathrm{~kg} / \mathrm{m}^{3}$, which allows it to narrow the passage of gasifier around the nozzle, so in this regard throat less gasifiers provide a proper design to solve the problem. Tar content and dust (tables 8 and 9) show pine needles emit more tar content compared to wood.

\section{Conclusion}

Pine needles can be used as an alternative fuel for a downdraft gasifier. Wood based gasifiers need some alteration in their design to more easily adapt with loose biomass and pine needles. As per the recommended norms of IIsc, Banglore, we have tested on a throat less gasifier. We obtained excellent results pertaining to cold gas, thermal and hot gas efficiencies. However, the results with using pine needle have been found to be better than that of those results obtained with wood, yet tar content value is slightly higher than wood. Calorific value of pine needle is found to be $18.57 \mathrm{MJ} / \mathrm{kg}$ that is higher than other loose biomass, such as rice husk, bagassese, coconut fibers, and rice straw. Combustion efficiencies of our gasifier, $97.13 \%$ (gross) and 76.66\% (net). Only $43 \%$ of total calorific value is lost in various components of gasifier plant, and remaining $57 \%$ is available for utilization at Engine. Of the total energy available at engine, $47 \%$ is lost to atmosphere (including conduction and radiation loss) (figure 10).

Alok Dhaundiyal obtained his Bachelor degree in Mechanical Engineering from Uttar Pradesh Technical University, Lucknow, Uttar Pradesh in 2009 and Master degree in Thermal Engineering from Govind Ballabh Pant University of Agriculture and Technology in 2014. He worked with Deutsche Gesellschaft für Internationale Zusammenarbeit (GIZ), which is a part of Indo-German Govt. Programme to promote renewable energy sector of India, under the patronage of state government agency of Uttrakhand, UREDA; and Central ministry, Ministry of New Renewable Energy. His areas of research interest include gasification of Pine needles, forest fire prevention in Uttrakhand, utilization of Himalayan resources and power generation for the hill hamlets of Uttrakhand. He also worked as Assistant professor in Uttrakhand Technical University and having Industrial experience of Automobiles Industries.

Corresponding address: alok.dext@hotmail.com

V. K. Gupta worked as Deputy Manager in Steel Authority of India Limited from 1982-83. He joined Govind Ballabh Pant University of Agriculture and Technology as Lecturer in 1983. He had been promoted as Assistant Professor in 1986. In 2005, he had been designated as Associate Professor in Govind Ballabh Pant University of Agriculture and Technology. He has been working as Professor in College of Technology, Govind Ballabh Pant University of Agriculture and Technology, Pantnagar, UK since 2006. He has published many International and National papers in various Journals. His field of Interest is Internal Combustion Engine and has expertise in Thermal Engineering.

Email:Vk.Vk.gupta@gmail.com

\section{References}

1 Bhavanam, Anjireddy and Sastry, R. C. 2011. Biomass Gasification Processes in Downdraft Fixed Bed Reactors: A Review. International Journal of Chemical Engineering and Applications. 2: 6-12

2 Gaur and Reed, S.T. 1995. An atlas of thermal data for biomass and other fuels. NREL/TB-433-7965, UC Category: 1310, DE95009212, National Renewable laboratory, Golden Colorado, USA

3 Germany. German Federal Government. Deutsche Gesellschaft für Internationale Zusammenarbeit. (GIZ) Report on Access to Energy. 2011.

4 United States of America. U.S. Energy Information Administration. Report on India is the fourth largest energy consumer in the world after the United States, China, and Russia. 2013

5 United Nations Development Programme (UNDP). New Delhi.

Report on Removal of Barriers to Biomass Power Generation in India. 2013.

6 Uttarakhand. Renewable Energy, Government of Uttarakhand. Uttarakhand Renewable Energy Development Agency. Bio-energy Programme. Report on Availability of Biomass in Uttarakhand. 2014.

7 ASME; 4.1 [PTC: 4]; 1998. Energy balance method 